\title{
Abad Keemasan dan Pembangunan Sosial di Negara Usmani abad ke-16: Pendekatan Struktur, Kultur dan Proses.
}

\author{
Frial R. Supratman \\ Pascasarjana Universitas Istanbul, Turki \\ Frialramadhan1@gmail.com
}

\begin{abstract}
Abstrak
Pembangunan sosial merupakan proses purba yang sudah ada sejak manusia itu ada. Tanpa pembangunan sosial peradaban maju tidak akan pernah bisa muncul. Dalam makalah ini penulis ingin menginvestigasi pembangunan sosial di masyarakat non-Barat pada periode modern awal yaitu di Negara Usmani (Ottoman State). Negara Usmani pada abad ke-16 sering dipandang sebagai negara adidaya dan abad ke-16 merupakan 'Abad Keemasan' (Golden Age) dari Negara Usmani, khususnya ketika Negara Usmani berada di bawah pemerintahan Sultan Suleyman Kanuni (1520-1566). Dalam hal ini kita ingin mencari tahu bagaimana pembangunan sosial yang terjadi di Negara Usmani. Pembangunan sosial yang dimaksud tentu saja bukan pembangunan sektoral, tetapi pembangunan yang menyeluruh sehingga menciptakan masyarakat yang partisipatif dengan melibatkan elemen dasar kehidupan sosial yaitu struktur, kultur dan proses. Dengan demikian maka kita akan mencari tahu bagaimana pembangunan sosial berjalan di Negara Usmani pada abad ke-16. Keberadaan pembangunan sosial ini diharapkan mampu menjadi bahan penilaian terhadap eksistensi "abad keemasan" yang selama ini menjadi perdebatan dalam historiografi sejarah Usmani.
\end{abstract}

Keywords: Social development; Ottoman; Golden Age; Structure; Culture; Process 


\section{Pendahuluan}

Abad keemasan atau golden age merupakan konsep yang bertumpu pada pendekatan sosiologi yang digagas oleh Ibn Khaldun pada abad ke-14. Ibn Khaldun menggagas mengenai bagaimana bangkit dan runtuhnya satu peradaban didasarkan seperti siklus hidup manusia yang dimulai dari fase kelahiran, pertumbuhan, dewasa, dan tua. Konsep ini kemudian digagas kembali oleh sejarawan Jerman yang bernama Oswald Spengler. ${ }^{1}$ Berbeda dengan konsep sejarah progresif yang digagas oleh Arnol Toynbee, Khaldun lebih mengutamakan teori siklus sehingga melihat peradaban sebagai proses kebangkitan dan keruntuhan. ${ }^{2}$ Dengan demikian menurut Ibn Khaldun setiap peradaban akan memiliki Abad Keemasan tersendiri yang nantinya diikuti oleh kejatuhan.

Dalam makalah ini penulis akan menginvestigasi Negara Usmani pada masa Abad Keemasan yaitu abad ke-16. Perdebatan kesarjanaan mengenai Abad Keemasan Negara Usmani sudah mengemuka sejak lama. Beberapa sejarawan setuju dengan adanya Abad Keemasan yang diikuti oleh keruntuhan, namun sebagian menolak adanya pendapat mengenai "abad keemasan." Daripada menggagas adanya "abad keemasan" mereka lebih memperhatikan adanya proses negosiasi dan adaptasi sehingga tidak melihat peradaban dari proses yang begitu kaku yaitu antara bangkit dan runtuh. ${ }^{3}$ Meskipun demikian kita harus mengakui bahwa abad ke-16 merupakan masa keemasan Negara Usmani karena Negara

\footnotetext{
${ }^{1}$ Keith Stimely, "Oswald Spengler: An Introduction to His Lifes and Ideas," https://www.ihr.org/jhr/v17/v17n2p-2_Stimely.html

${ }^{2}$ Syed Farid Alatas.Applying Ibn Khaldun: The Recovery of a Lost Tradition in Sociology (New York: Routledge, 2014), hlm 65.

${ }^{3}$ Karen Barkey.Empire of Difference: The Ottomans in Comparative Perspective (New York:

Cambridge University Press, 2008), hlm 22; Ernest Gellner.Muslim Society (New York: Cambridge University Press, 1981), hlm 74.
}

62 | TamaddunVol. 7 , No. I, Januari - Juni 2019 
Usmani melakukan pembangunan sosial yang menyeluruh dan tidak hanya menekankan pada sektor tertentu saja. Tidak hanya bertumpu pada pertumbuhan ekonomi, Negara Usmani juga memperhatian aspek sosial humaniora sebagai upaya dalam membangun masyarakat.

Dalam penelitian ini penulis ingin melihat Negara Usmani melalui pendekatan sosiologis. Tujuan utama penulis adalah ingin melihat pembangunan sosial yang dilakukan Negara Usmani pada masa abad keemasannya berlangsung, sekaligus membuktikan keberadaan "abad keemasan" melalui investigasi atas pembangunan sosial. Dengan melihat Negara Usmani sebagai studi kasus, maka ini akan memperluas perspektif kita mengenai pembangunan sosial. Selama ini kita hanya terfokus pada pembangunan sosial masa kontemporer ketika masyarakat hidup dibawah kekuasaan negara-bangsa (nation state) sehingga kita mengabaikan pembangunan yang dilakukan ketika imperium-imperium ketika mereka masih berdiri. Dengan cara pandang yang seperti itu maka kita mengabaikan fakta bahwa pembangunan sosial yang bertumpu pada elemen dasar kehidupan manusia seperti struktur, kultur dan proses pernah terjadi ketika imperium-imperium itu berdiri. Dalam hal ini penulis akan menunjukkan bahwa Negara Usmani pada abad ke-16 berhasil melakukan pembangunan sosial yang holistik dan mampu meningkatkan kualitas kehidupan masyarakat.

\section{Metode Penelitian dan Pendekatan}

Metode penelitian yang akan dipakai dalam penelitian ini adalah metode sejarah. Metode sejarah merupakan upaya yang dilakukan oleh sejarawan dalam melakukan rekonstruksi masa lampau dengan jelas sehingga masa lalu dapat tergambarkan dan terkonsep secara holistik. Untuk itu metode sejarah yang baik adalah yang melibatkan keberadaan sumber primer di dalamnya. Sumber primer dalam metode sejarah adalah sumber yang diproduksi pada zaman yang sedang 
diteliti. Dalam penelitian abad ke-16 tentunya penulis menggunakan manuskripmanuskrip yang diproduksi pada abad ke-16. Meskipun demikian penulis tidak menggunakan manuskrip asli, tetapi menggunakan manuskrip yang sudah diterbitkan. Sebagai contoh penulis menggunakan manuskrip karya Peçevi İbrahim Efendi berjudul Peçevi Tarihi. Namun penulis tidak menggunakan manuskrip Peçevi Tarihi yang asli, tetapi lebih memilih menggunakan Peçevi Tarihi yang sudah diterbitkan oleh penerbit terbaru karena penulis lebih memfokuskan penelitian yang menekankan bagaimana mengkonsepkan masa lampau yang didasarkan pada problem sosial ketimbang pada penemuan fakta-fakta baru. Beberapa manuskrip yang digunakan untuk penulisan ini kebanyakan sudah diterbitkan ulang sehingga mempermudah penulis dalam membaca dan mengaksesnya.

Adapun pendekatan yang dipakai penulis untuk melakukan penelitian ini adalah dengan menggunakan pendekatan sosiologi. Pendekatan sosiologi sangat membantu penulis dalam melihat sejarah sehingga kita bisa mengkonsepkan masa lalu dengan lebih sistematis, bukan hanya menguraikan hanya fakta-fakta baru. Dalam penelitian ini penulis akan mencoba meneliti pembangunan sosial melalui pendekatan struktur, kultur dan proses. Menurut Paulus Wirutomo, pembangunan sosial adalah, "pembangunan elemen dasar dari kehidupan sosial yaitu struktur, kultur dan proses sosial." Jadi pembangunan sosial bukan hanya bertumpu pada pembangunan sektor ekonomi yang berorientasi pada pertumbuhan dan aspekaspek kuantitatif tetapi bertumpu pada bidang sosial humaniora dengan aspek kualitatif. Dengan demikian tujuan daripada pembangunan sosial adalah adanya kesejahteraan sosial humaniora yang mneyeluruh di segala bidang. Salah satu

\footnotetext{
${ }^{4}$ Paulus Wirutomo, "Mencari Makna Pembangunan Sosial: Studi Kasus Sektor Informal di Kota Solo," dalam Masyarakat: Jurnal Sosiologi, Vol 18, No.1, (2013), hlm 106.

file://C:/Users/personal/Downloads/3735-7073-2-PB.pdf
} 
tujuan daripada pembangunan ini adalah adanya partisipasi masyarakat, adanya budaya multikulturalisme dan interaksi sosial yang dinamis.

Struktur merupakan elemen penting bagi pembangunan sosial. Dalam struktur terdapat kekuatan yang memaksa untuk melakukan suatu perubahan. Pemerintah memiliki perangkat negara yang mampu memaksa masyarakat untuk melakukan perubahan. Perubahan yang didukung oleh struktur biasanya bersifat memaksa dan masyarakat harus mematuhi apa yang telah distrukturkan oleh negara. Jika tidak, maka masyarakat harus menerima sanksi berupa hukuman. Di dalam Negara Usmani, kekuasaan tertinggi dikepalai oleh seorang sultan yang berperan penting dalam mengatur jalannya negara. Namun sultan seringkali mendelegasikan wewenangnya kepada sadrazam (setara dengan perdana menteri). Kemudian sadrazam memiliki perangkat lainnya yang menjadi struktur pemerintahan seperti para wazir, beylerbeyi, kadiasker, mufti, kadi dan lain-lain. Mereka merupakan bagian dari kekuatan struktur yang mampu mendorong perubahan seperti mengeluarkan dokumen atau sertifikat keputusan (ferman, berat dan lain-lain) hingga menciptakan hukum (syariat dan kanun) yang dapat memaksa masyarakat untuk mematuhinya. Kekuatan struktur tentu mampu merubah masyarakat sebagai sistem sehingga pembangunan dapat dilakukan secara berkelanjutan.

Kultur merupakan kebiasaan yang sudah lama berkembang dan mengakar dalam masyarakat. Sifat dari kultur adalah sukarela dan tidak memaksa. Berbeda dari struktur yang dipaksakan oleh pemerintah, masyarakat tidak pernah memaksakan seseorang untuk menjalankan satu kultur tertentu sehingga kultur tidak dapat mendorong satu perubahan secara cepat dan langsung. Proses yang panjang diperlukan untuk merubah masyarakat melalui kultur. Negara Usmani pada abad ke-16 adalah negara yang multikultur, tidak dikuasai oleh satu kultur etnik atau agama tertentu. Meskipun Islam menjadi agama resmi negara, namun Negara 
Usmani tidak memaksakan pemeluk agama lain untuk menjadi Muslim. Negara membiarkann agama-agama lain berkembang di Negara Usmani dengan mengangkat pemimpin masing-masing agama untuk memimpin pemeluknya dalam kehidupan sosial dan kebudayaan. Pemeluk Kristen Ortodoks dipimpin oleh Patriarch, Muslim dipimpin oleh Kadi, sedangkan Yahudi dipimpin oleh Rabbi. Agen penting yang menstrukturkan kultur adalah Syaikhulislam. Syaikhulislam merupakan seorang ulama yang diangkat oleh sultan untuk memberikan fatwa mengenai satu permasalahan. Meskipun fatwa cenderung merupakan satu opini, tetapi posisi Syaikhulislam yang dekat dengan sultan mampu menstrukturkan kultur dan memproseskan kultur.

Proses sosial adalah interaksi timbal balik di dalam masyarakat untuk mendukung pembangunan. Dalam Negara Usmani yang disusun berdasarkan sistem patrimonial, tentu kita tidak akan menemukan nilai-nilai demokratis yang membuat masyarakat berpatisipasi secara langsung, tetapi Negara Usmani memiliki media yang digunakan untuk melakukan interaksi sosial. Salah satu tempat untuk melaksanakan interaksi sosial dalam melakukan pembangunan adalah kedai kopi (kahvehane). Tempat tersebut mencerminkan bagaimana masyarakat berpartisipasi dalam pembangunan. Selain itu imaret (fasilitas sosial seperti masjid dan madrasah) merupakan tempat masyarakat melakukan interaksi. Di tempat-tempat tersebut masyarakat mampu melakukan negosiasi, membicarakan konflik, sehingga mampu memberikan sumber bagi perubahann struktur dan kultur. Menurut Paulus, membangun proses sosial artinya "membangun kondisi struktural dan kultural di dalam masyarakat yang memberi ruang lebih luas bagi pembangunan kuantitas maupun kualitas proses sosial itu sendiri."

\footnotetext{
${ }^{5}$ Paulus Wirutomo, “Mencari Makna Pembangunan Sosial,” hlm 108.
} 


\section{Negara Usmani dan Abad Keemasan}

Kelahiran Negara Usmani tidak dapat dilepaskan dari adanya gelombang migrasi dari suku nomaden Turki (beylik) dari Asia Tengah dan Eurasia ke Anatolia. Menurut sejarawan Halil Inalcik, terdapat dua fase penting yang menandai migrasi nomaden Turki ke Anatolia. Pertama, kemenangan Sultan Alparslan dari Seljuk Besar atas Imperium Bizantium dalam Pertempuran Malazgirt tahun 1071. Dengan kemenangan tersebut Kesultanan Seljuk Besar memperluas wilayah kekuasaannya dan mendorong masukanya suku nomaden Turki ke wilayah kekuasaan Imperium Bizantium di Anatolia. Kedua, adanya invasi Mongol ke Asia Tengah dan Eurasia pada abad ke-13. ${ }^{6}$ Serangan yang dilakukan oleh Mongol menyebabkan nomaden Turki melakukan migrasi besarbesaran ke wilayah Anatolia. Patronase Kesultanan Seljuk Anatolia pada abad ke13 juga mempermudah suku nomaden Turki untuk mendapatkan perlindungan. Ertugrul Gazi (wafat 1281) adalah seorang pemimpin suku nomaden Turki yang membantu Kesultanan Seljuk Anatolia untuk melawan Bizantium. Keturunan Ertugrul, Osman Gazi, kemudian mendirikan Negara Usmani sejak kemenangannya melawan Bizantium dalam Perang Bapheus 1302. Sejak itu Negara Usmani terus memperluas kekuasaannya dari Balkan hingga ke Anatolia. Tahun 1453 Negara Usmani dibawah Sultan Mehmet II atau Fatih (1444-1481) berhasil menaklukkan Konstantinopel, ibukota Bizantium, lalu namanya diubah menjadi Istanbul.

Keberhasilan Mehmet II dalam menaklukkan Konstantinopel tahun 1453, telah menjadi titik balik bagi jalannya sejarah dunia. Sebagian sejarawan menyatakan bahwa jatuhnya Konstantinopel, mendorong kemunculan renaisans untuk dunia Eropa. Dalam perspektif sejarah Negara Usmani, penaklukkan

\footnotetext{
${ }^{6}$ Halil Inalcik.The Ottoman Empire The Classical Age 1300-1600 (New Haven: Phoenix, 2001), hlm 21 .
} 
Konstantinopel menjadi awal bagi sentralisasi dan birokratisasi Usmani sebagai sebuah negara. Jika sebelum tahun 1400, Negara Usmani masih belum memiliki pengadministrasian yang begitu baik, maka pasca 1400, Negara Usmani sudah lebih baik dalam membentuk birokrasi terpusat yang puncaknya terjadi pada masa Sultan Suleyman Kanuni (1520-1566). Banyak sejarawan menganggap bahwa masa Suleyman Kanuni pada abad ke-16 merupakan 'Abad Keemasan' dari Negara Usmani.

Konsep Abad Keemasan sebenarnya mengacu pada historiografi tradisional yang melihat sejarah dalam pendekatan bangkit dan runtuh. Ketika kita melihat sejarah dalam format 'bangkit dan runtuh' (rise and decline) maka, tidak diragukan lagi, kita akan melihat adanya satu puncak pencapaian dari satu negara. Puncak pencapaian tersebut seringkali disebut dengan 'abad keemasan' atau 'abad kejayaaan.' Pola historiografi yang menekankan aspek 'bangkit dan runtuh' terdapat dalam pemikiran sosiolog Ibn Khaldun. Pada Muqaddimah dan Kitab alIbar, Ibn Khaldun menjelaskan pembentukan dan keruntuhan negara-negara Arab dan Maghrib. Menurut Ibn Khaldun, masyarakat cenderung bergerak dari masyarakat nomaden ke masyarakat menetap. Menurut sosiolog Farid Alatas, Kohesi sosial (social cohesion) yang dapat mengikat masyarakat adalah rasa asabiyyah atau perasaan solidaritas diantara anggota kelompok yang diperoleh dari pengetahuan bahwa mereka berasal dari keturunan yang sama (common descent). ${ }^{7}$ Rasa asabiyyah yang kuat di antara masyarakat nomaden biasanya akan memudahkan satu kelompok membentuk negara. Mereka akan menggantikan kelompok menetap dengan rasa asabiyyah yang lemah. Jadi, ketika negara sudah sampai pada puncak peradabannya dengan menjadi masyarakat menetap maka negara akan semakin terkikis rasa asabiyyah-nya. Hal ini akan membuka jalan bagi keruntuhan negara tersebut.

\footnotetext{
${ }^{7}$ Syed Farid Alatas.Applying Ibn Khaldun, hlm 65.
} 
Berdasarkan konsep pembentukan dan kejatuhan negara yang digagas oleh Ibn Khaldun, maka kita melihat bahwa Negara Usmani juga mengalami fase yang sama yaitu fase masyarakat nomaden dan masyaraat menetap. Ketika pendiri Negara Usmani, Osman Gazi (1299-1323), bertempur melawan Imperium Bizantium dalam Perang Bapheus 1302, maka Negara Usmani masih berada dalam fase nomaden karena Osman Gazi (1299-1323) belum memiliki perangkat negara dan ibukota yang tetap bagi kekuasaan politiknya. Sedangkan ketika itu Imperium Bizantium berada dalam fase menetap sehingga rasa asabiyyah mereka mulai terkikis akibat dari puncak kejayaan yang dinikmatinya. Kebalikannya rasa asabiyyah dari klan Osman semakin menguat dan mampu mengikis kekuatan Imperium Bizantium. Setelah Osman Gazi (1299-1323) mengalahkan Bizantium tahun 1302, maka sebenarnya Usmani sudah berada dalam tahap transformasi menuju masyarakat menetap. Sebelum Istanbul, bahkan Negara Usmani sudah memiliki ibukota di Edirne dan Bursa berkat penaklukkan yang dilakukan olehnya, namun Istanbul merupakan ibukota Negara Usmani yang terakhir sehingga dalam fase ini, khususnya setelah penaklukkan Konstantinopel 1453, Usmani sudah berada dalam fase masyarakat menetap.

Setelah mencapai fase menetap, maka Negara Usmani dapat memfokuskan usahanya untuk pembentukan negara (state formation). Pembentukan negara ini meliputi berbagai aspek seperti birokrasi, militer, keagamaan yang dapat menopang pembangunan sosial ekonomi di Negara Usmani. Kemampuan klan Osman dalam membentuk negara mencapai puncaknya pada masa kekuasaan Sultan Suleyman Kanuni (1520-1566). Periode kekuasaannya dianggap sebagai puncak kejayaan dan abad keemasan bagi Negara Usmani. Pada masa pemerintahannya, Negara Usmani memiliki wilayah kekuasaan yang begitu luas dari mulai Afrika Utara, Balkan (Eropa Tenggara), Anatolia hingga Semenanjung Arab. Untuk itu masa kekuasaan 
Suleyman Kanuni (1520-1566) dianggap sebagai masa abad kejayaan atau abad keemasan (the golden age).

Selain Ibn Khaldun, tentu saja para ilmuwan Usmani juga mendasarkan pendekatan "abad keemasan" dan "bangkit dan keruntuhan" dari berbagai literatur dari tradisi Persia, Asia Tengah dan Islam. Beberapa literatur yang sering dipakai sebagai refrensi mengenai "keruntuhan" sebuah negara adalah nasihatname. ${ }^{8}$ Nasihatname merupakan buku yang ditulis oleh para ilmuwan atau ulama untuk memberikan saran serta masukan kepada penguasa. Salah satu nasihatname yang terkenal pada masa pemerintahan Sultan Suleyman Kanuni adalah Asafname yang ditulis tahun 1541 oleh Lutfu Paşa. Begitu juga buku Risale yang ditulis oleh Koçi Bey pada masa pemerintahan Sultan Murat IV (1623-1640). Sumber tersebut biasanya dipakai oleh para ahli pendukung pendekatan "bangkit dan keruntuhan" dan "abad keemasan."

Meskipun demikian terdapat beberapa kritik dari pendekatan abad keemasan ini. Sebagian ahli menyatakan bahwa pendekatan Khaldunian mengenai "abad keemasan" dan "kebangkitan dan keruntuhan" tidak cocok diterapkan dalam Negara Usmani. Sosiolog Ernest Gellner menyatakan bahwa Negara Usmani tidak cocok dengan pendekatan Khaldunian karena Negara Usmani adalah negara yang stabil dan berumur panjang (long-lived).$^{10}$ Kritik terhadap pendekatan "bangkit dan runtuh" dan "abad keemasan" juga datang dari sosiolog Karen Barkey. Barkey menyatakan bahwa terminologi "keruntuhan" (decline) merupakan produk yang mempertentangkan kemajuan Eropa dan kemunduran peradaban Islam. Dengan demikian daripada melihat "keruntuhan" Negara Usmani, Karen Barkey lebih

\footnotetext{
${ }^{8}$ Halil Inalcik.The Ottoman Empire The Classical Age 1300-1600, hlm 17.

${ }^{9}$ Linda T. Darling. Revenue-Raising and Legitimacy: Tax Collection and Finance Administration in the Ottoman Empire 1560-1660 (Leiden, New York, Koln: Ej. Brill, 1996), hlm 3.

${ }^{10}$ Ernest Gellner.Muslim Society, hlm 74.
} 
melihat bagaimana usaha Negara Usmani melakukan adaptasi setelah abad ke-16. ${ }^{11}$ Selain Gellner dan Barkey tentu masih banyak lagi ahli ilmu sosial dan sejarawan yang mengkritik mengenai pendekatan "keruntuhan" dan "abad keemasan". ${ }^{12}$ Kebanyakan dari para pengkritik pendekatan "abad keemasan" dan "kebangkitan dan keruntuhan" menyatakan bahwa pendekatan tersebut terlalu Eurosentris karena menempatkan Negara Usmani dalam situasi yang inferior ditengah perkembangan Eropa yang melesat pada abad ke-17.

Meskipun terdapat beberapa kritik terhadap pendekatan "abad keemasan" dan "kebangkitan dan keruntuhan," namun penulis merasa bahwa memberikan pendekatan "abad keemasan" dalam melihat sejarah Negara Usmani masih diperlukan guna memahami apa yang menjadi titik tolak kemajuan dan kemunduran satu negara. Jika kita tidak dapat melihat adanya "abad keemasan" maka kita akan sulit melihat dan mendeteksi gejala-gejala kemunduran itu sendiri. Kebanyakan para pengkritik pendekatan "abad keemasan" selalu menganalisa dari perspektif politik ekonomi. ${ }^{13}$ Mereka nampak gagal melihat "abad keemasan" dari perspektif pembangunan sosial yang menyeluruh. Untuk itu pembangunan sosial melalui pendekatan teori struktur, kultur dan proses sangatlah dibutuhkan untuk melihat apakah Negara Usmani benar-benar mencapai "abad keemasan."

\footnotetext{
${ }^{11}$ Karen Barkey.Empire of Difference, hlm 22.

${ }^{12}$ Linda T. Darling. Revenue-Raising and Legitimacy, hlm 6; Rifa'at Abou El-Haj.Formation of the Modern State: the Ottoman Empire Sixteenth to Eighteenth Century (New York: Syracuse University Press, 2005),hlm 26; Cornell Fleischer.Tarihçi Mustafa Ali: Bir Osmanlı Aydın ve Bürokratı (İstanbul: Türkiye Ekonomik ve Toplumsal Tarih Vakfi, 1996), hlm 306; Cemal Kafadar "The Myth of Golden Age: Ottoman Historical Consciousness in the Post-Suleymanic Era," dalam Halil Inalcik dan Cemal Kafadar (ed).Suleyman The Second and His Time (Istanbul: ISIS, 1993), hlm 36.

${ }^{13}$ Linda T. Darling. Revenue-Raising and Legitimacy, hlm 299.
} 


\section{Pembangunan Struktural}

Elemen pertama yang dipakai untuk melihat pembangunan sosial adalah elemen struktur. Ini merupakan elemen yang mampu mengubah masyarakat secara paksa seperti melalui peraturan pemerintah, larangan, hingga hukum. Masyarakat yang tidak mematuhi kekuatan struktur akan menerima konsekuensi melalui hukuman. Negara Usmani memili perangkat negara yang berperan dalam menciptakan pembangunan sosial melalui kekuatan struktur. Hierarki tertinggi dalam Negara Usmani tentu saja ditempati oleh sultan yang kekuasaannya absolut. Legitimasi keagamaan turut memperkuat posisi sultan yang absolut. Gelar gazi, kaisar hingga khalifah merupakan kekuatan yang dapat memperkuat sultan dalam puncak struktur kekuasaan. ${ }^{14}$ Sultan Selim I (1512-1520) misalnya memperoleh gelar khalifah (wakil Tuhan di bumi) untuk melegitimasi kekuasaannya. Sedangkan Sultan Suleyman Kanuni (1520-1566) digelari sebagai "Sah dari Baghdad dan Irak," "Kaisar Romawi" dan "Sultan Mesir." ${ }^{15}$ Gelar ini menempatkan sultan dalam posisi yang sakral dan mampu mengatur negara dengan absolut. Di tengah masyarakat yang masih mempercayai adanya persatuan politik dan agama, maka gelar-gelar imperial dan monarki memainkan peran yang signifikan.

Sebagai penguasa yang memiliki wewenang yang absolut, tentu saja sultansultan Negara Usmani tidak membiarkan negaranya berjalan tanpa hukum. Mengeluarkan sebuah hukum atau peraturan merupakan salah satu kekuatan struktural yang paling kuat. Dengan adanya hukum yang dapat digunnakan untuk mendukung kestabilan sosiall ekonomi maka Negara Usmani sebenarnya telah

\footnotetext{
${ }^{14}$ Peçevi İbrahim Efendi.Peçevi Tarihi 1 (penerjemah: Bekir Sıtkı Baykal) (Ankara: Başbakanlı Matbaas1, 1981), hlm 235.

${ }^{15}$ Dariusz Kolodziejczyk, "Khan, Caliph, Tsar and Imperator: The Multiple Identites of Ottoman Sultan," dalam Peter Fibiger Bang \& Dariusz Kolodziejczyk (ed).Universal Empire: A Comparative Approach to Imperial Culture and Representation in Eurasian History (New York: Cambridge University Press, 2012), hlm 182; H. Erdem Çıpa.The Making of Selim: Succession, Legitimacy and Memory in the Early Modern Ottoman World (Indiana: Indiana University Press, 2017), hlm 90;
} 
mendukung adanya pembangunan sosial. Negara Usmani membentuk hukum kanun yang menjadi pondasi pengorganisasian satu negara. ${ }^{16}$ Suleyman Kanuni mendapat gelar "Kanuni” karena menjadi pemimpin yang mampu menciptakan hukum kanun yang bermanfaat untuk pembangunan sosial. Hukum kanun yang diciptakan oleh Sultan Suleyman Kanuni (1520-1566) sebenarnya merupakan keberlanjutan dari Kanunname yang digagas oleh Sultan Mehmet II (1444-1481) Fatih. Hukum ini merupakan hukum sekular yang diciptakan untuk menjalankan negara. Pemerintah pusat biasanya mengeluarkan peraturan-peraturan sesuai dengan kebutuhan dari wilayah tertentu. Hukum ini ditulis oleh seorang sekretaris kemudian diserahkan kepada sadrazam (setara dengan Perdana Menteri) dan Nişancı (Chancellor). Mereka kemudian menyampaikan kepada sultan mengenai hal ini. Setelah dikonfirmasi maka kanun secara resmi dapat digunakan. ${ }^{17}$ Tentu saja pembentukan kanun merupakan upaya yang dilakukan oleh sultan dan para pejabat negara untuk mempermudah Negara Usmani dalam mengatur masyarakat. Dengan adanya kanun maka kesewenang-wenangan dari pejabat lokal dapat dihindari. Dengan demikian kontrol antara satu pejabat dengan jabatan lain atas kanun dan syariat selalu eksis. Seorang gubernur (beylerbeyi) tidak dapat memutuskan perkara tanpa persetujuan dari hakim (kadi). Adanya kanun ternyata sangat bermanfaat untuk mencegah adanya kesewenang-wenangan dalam masyarakat.

Sebenarnya dari sini terdapat nilai struktur yang diambil dari kebudayaan atau dengan kata lain terdapat budaya yang distrukturkan (structured culture). Hal ini merupakan bentuk dan terobosan yang dilakukan oleh sultan-sultan Usmani selama abad ke-16 untuk melakukan pembangunan sosial. Keberadaan kanun yang

\footnotetext{
${ }^{16}$ Hukum Negara Usmani terbagi menjadi hukum kanun dan hukum syariat, lihat: Halil İnalcik, "Kanun and Shariah," hlm 1-12. http://www.inalcik.com/images/pdfs/29922311KANUNANDSHARiAH.pdf

${ }^{17}$ Halil Inalcik.The Ottoman Empire The Classical Age 1300-1600, hlm 114,
} 
sangat efektif diterapkan pada masa Suleyman Kanuni (1520-1566) merupakan impelementasi atas nilai-nilai budaya yang dianut oleh Negara Usmani. Islam merupakan sumber kebudayaan yang sangat esensial dalam Negara Usmani. Bahkan Sejak Negara Usmani menaklukkan Kesultanan Mamluk 1517, maka sultan Selim I (1512-1520) menerima pengakuan dari Syarif Mekkah. Ini menyimbolkan Usmani sebagai penjaga dua kota suci Mekkah dan Madinah sehingga Selim I pantas menyandang gelar Khalifah. Beban sultan Negara Usmani dalam menyandang gelar khalifah harus diimplementasikan dengan sikap sultan yang berlaku adil terhadap masyarakat. Dalam kebudayaan Islam terdapat konsep adalet (keadilan). Adalet dapat diartikan sebagai satu sikap berdasarkan hukum dan kesetaraan. Dalam al-Quran, adalet diartikan sebagai jalan yang lurus, keseimbangan, kesetaraan, kejujuran hingga kenetralan. ${ }^{18}$ Atas dasar itu maka khalifah harus menganut nilai-nilai adalet. Untuk mewujudkan adalet, maka sultan-sultan Usmani abad ke-16, memutuskan untuk menciptakan kanun. Kanun sendiri adalah hukum kreatif diluar syariat yang diciptkan untuk mengimplementasikan nilai-nilai adalet. Selain itu salah satu sikap adalet dapat dilihat dalam beberapa karya sejarawan abad ke-16 seperti Ibrahim Pecevi Efendi yang berjudul Pecevi Tarihi. ${ }^{19}$

Dengan adanya kanun, maka diharapkan adalet dapat terwujud dimana masyarakat diperlakukan dengan adil dan baik di depan hukum. Kemampuan kanun dalam menjaga kestabilan sosial di masyarakat terlihat dengan adanya kemampuan kanun dalam melayani sistem perpajakan. Kanun telah mengatur dengan baik siapa yang menarik pajak, berapa besar pajak yang ditarik, tanah-tanah mana saja yang dikenai pajak. Hal tersebut tentu saja mendorong adanya pembangunan sosial yang berdasarkan nilai adalet atau keadilan. Meskipun dalam

\footnotetext{
${ }^{18}$ Mustafa Çağrıcı, “Adalet,” dalam Diyanet Islam Ansiklopedisi jilid 1 (1988), hlm 341. http://www.islamansiklopedisi.info/dia/pdf/c01/c010419.pdf

${ }^{19}$ Peçevi İbrahim Efendi.Peçevi Tarihi 1, hlm 4.
} 
Negara Usmani pembayaran pajak atas Muslim dan non-Muslim dibedakan, namun sebenarnya kanun telah membedakannya dengan adil. Seorang non-Muslim biasanya dikenakan pajak khusus (jizya), sedangkan Muslim tidak. Namun pada gilirannya, Muslim harus berperang dan menjadi militer, namun non-Muslim tidak karena taat membayar pajak. Begitu juga karena taat membayar pajak, maka keberadaan non-Muslim dilindungi.

Peran negara dalam pembangunan sosial juga dapat terlihat dari adanya budaya beramal yang kemudian distrukturkan melalui kebijakan wakaf. Hal ini sebenarnya sudah ada sejak abad ke-14 dengan berdirinya Madrasah Suleyman Paşa di kota Iznik, namun pembangunan fasilitas sosial (imaret) mencapai puncaknya pada masa Sultan Suleyman Kanuni. Islam mengajarkan umatnya untuk beramal yaitu menyisihkan sebagian hartanya untuk membantu masyarakat yang kurang mampu. Kebudayaan yang sudah berakar lama sejak turunnya Islam di Arab abad ke-7 kemudian diadopsi oleh Negara Usmani dalam kebijakan struktural yang bermanfaat untuk masyarakat.

Untuk mengakomodir masyarakat Usmani dalam beramal, maka Negara Usmani mengatur adanya kepemilikan tanah yang dikontrol negara. Pada abad ke16 Seyhulislam (Pemimpin para ulama yang bertugas memberi fatwa) Ebu Suud Efendi menyatakan bahwa seluruh tanah adalah milik negara. ${ }^{20}$ Dengan demikian maka Negara Usmani mampu menyisihkan tanah negara tersebut menjadi tanah wakaf. Tidak seperti tanah lainnya, tanah ini tidak boleh ditarik pajak. Untuk itu biasanya pemasukan dari tanah ini digunakan untuk membiayai pembangunan fasilitas sosial (maret) seperti masjid, sekolah (medrese), rumah sakit, penginapan (misafirhane), kanal air, jalan, jembatan, pasar serta hamam. Salah satu proyek prestisius dari Sultan Suleyman Kanuni (1520-1566) dalam membangun fasilitas

\footnotetext{
${ }^{20}$ M. Şükrü Hanioğlu.A Brief History of Late Ottoman Empire (New Jersey: Princeton University Press, 2008), hlm 20.
} 
sosial adalah pembangunan Masjid Suleymaniye di Istanbul. Proses pembangunan masjid yang berlangsung dari tahun 1544/45 hingga 1556 dicatat dengan jelas oleh pelancong Usmani abad ke-17, Evliya Çelebi dalam buku Seyahatname. ${ }^{21}$ Penulis biografi bernama Sai Mustafa Çelebi dalam bukunya Tezkiretü'l Bünyan ve Tezkiretü'l-Enbiye, juga mencatat bagaimana Mimar Sinan, arsitektur Usmani ternama, membangun Masjid Suleymaniye dengan sangat indah. ${ }^{22}$ Pembangunan fasilitas sosial ini tentu saja banyak dirasakan manfaatnya oleh masyarakat luas. Pembangunan çesme atau tempat penampungan air bersih tentu saja sangat bermanfaat agar masyarakat dapat minum air bersih dengan gratis. Penulis abad ke-16, Sai Mustafa Çelebi mencatat dengan detail siapa saja yang mendonasikan hartanya untuk pembangunan çesme. ${ }^{23}$ Proyek imaret atau fasilitas sosial yang paling berpengaruh terhadap upaya dalam mengubah mentalitas masyarakat adalah sekolah (medrese). Sekolah merupakan fasilitas sosial yang paling penting di Negara Usmani setelah masjid. Setidaknya seluruh masyarakat Usmani mendapatkan pendidikan dasarnya dari sekolah tersebut. Antara tahun 1550-1556 Sultan Suleyman Kanuni bahkan membangun sekolah khusus ilmu hadis dan ilmu kedokteran. Keberadaan lembaga wakaf yang didorong secara struktural oleh pemerintah telah melahirkan berbagai macam fasilitas sosial yang sangat bermanfaat untuk masyarakat.

\section{Pembangunan Kultural}

Elemen kedua dalam pembangunan sosial adalah pembangunan kebudayaan. Seperti yang telah disebutkan di atas, pembangunan sosial bukan hanya terpusat pada angka-angka dan data yang bersifat kuantitatif, tetapi juga memperhatikan aspek kualitatif dari kehidupan sosial kebudayaan. Pembangunan

\footnotetext{
${ }^{21}$ Evliya Çelebi. Günümüz Türkçesiyle Evliya Çelebi Seyahatnamesi: İstanbul (edit oleh Seyit Ali Kahraman-Yücel Dağşı) (İstanbul: Yapı Kredi Yayınları 2006), hlm 111-112; Stefanos Yerasimos.Süleymaniye (İstanbul: Yap1 Kredi Yayınları 2002) hlm 97-98.

${ }^{22}$ Sai Mustafa Çelebi.Tezkiretü'l Bünyan ve Tezkiretü'l-Enbiye: Mimar Sinan 'ın Anılarl (edit oleh Doğan Kuban) (İstanbul: Koç Kültür Sanat Tanıtım A.Ş, 2003), hlm 63.

${ }^{23}$ Sai Mustafa Çelebi.Tezkiretü'l Bünyan ve Tezkiretü'l-Enbiye, hlm 58.
} 
sektoral yang berpusat pada kegiatan ekonomi semata akan menimbulkan kepincangan dalam masyarakat. Dalam Negara Usmani aspek paling penting dalam sektor kebudayaan tentu saja adalah agama. Islam merupakan agama resmi yang dianut oleh Negara Usmani, setidaknya hal itu ditunjukkan dengan dipakainya syariat Islam sebagai bagian dari hukum Usmani, di samping hukum kanun. Upaya struktural lain untuk membangun kultur atau kebudayaan dapat terlihat dari adanya pengadopsian pemikiran para intelektual muslim ke dalam sistem pendidikan Negara Usmani. Negara Usmani memiliki banyak sekali pemikir Muslim beserta karya-karyanya, namun dalam makalah ini penulis hanya ingin memaparkan satu intelektual Muslim saja yang pemikirannya telah diadopsi dalam sistem pendidikan Usmani.

Salah satu intelektual atau ulama Negara Usmani yang pemikirannya menjadi elemen penting dalam pembangunan sosial, terutama dalam bidang pendidikan adalah Taşköprizade Ahmed Efendi (wafat 1561). Taşköprizade Ahmed Efendi lahir di kota Bursa pada 2 Desember 1495. Dia merupakan anak seorang guru yang pandai dalam bidang agama. Masa kecilnya dihabiskan untuk mencari ilmu dari satu madrasah ke madrasah lain di berbagai kota seperti kota Bursa, Amasya, Dimetoka, hingga Istanbul. Setelah lulus pendidikan Taşköprizade Ahmed Efendi meniti karir menjadi seorang guru. Pada tahun 1545 dia menjadi hakim (kadi) di kota Bursa untuk kemudian dipindahkan sebagai hakim (kadi) di Istanbul tahun $1551 .^{24}$ Banyak karyanya yang monumental membicarakan mengenai sistem pendidikan. Salah satu kontribusi Taşköprizade Ahmed Efendi adalah pembagian cabang ilmu pengetahuan yang nantinya akan menjadi dasar pendidikan sekolah di Negara Usmani. Menurut Taşköprizade Ahmed Efendi ilmu

\footnotetext{
${ }^{24}$ Yusuf Şevki Yavuz, "Taşköprizade Ahmed Efendi,” dalam Diyanet Islam Ansiklopedisi jilid 40 (2011), hlm 151. http://www.islamansiklopedisi.info/dia/pdf/c40/c400077.pdf
} 
pengetahuan terbagi menjadi empat bagian beserta subdivisinya. Adapun ilmu-ilmu tersebut adalah sebagai berikut:

1. Ilmu kaligrafi: penulisan, gaya menulis dll.

2. Ilmu Oral: Bahasa Arab dan fonetiknya, leksikografi, etimologi, tata bahasa dan syntax, retorika, prosody, puisi, komposisi, sejarah dan ilmu-ilmu literatur lainnnya.

3. Ilmu intelektual: logika dan dialektik

4. Ilmu spiritual: teori umum, ilmu alam, matematika, etika, ilmu politik, alQuran, fikih, etika dll. ${ }^{25}$

Pemikiran Taşköprizade Ahmed Efendi di atas merupakan produk kebudayaan yang kemudian dimanfaatkan ke dalam program pemerintah Negara Usmani. Dengan demikian banyak sekali sekolah-sekolah di Negara Usmani yang dibangun berdasarkan cabang keilmuann di atas. Selain itu maka kita juga mengetahui bahwa pemerintah melakukan strukturisasi cabang-cabang ilmu tersebut ke dalam kurikulum pendidikan di Negara Usmani. Selain memperkenalkan diversifikasi ilmu pengetahuan, Taşköprizade Ahmed Efendi juga memperkenalkan dan membawa pengaruh Mazhab Hanafi dalam pendidikan di Negara Usmani melalui buku-bukunya. ${ }^{26}$ Dengan demikian dalam hal ini kita mengetahui bahwa terdapat kultur yang distrukturkan (structured culture) melalui pemikiran Taşköprizade Ahmed Efendi. Pemikiran Taşköprizade Ahmed Efendi kemudian diadopsi melalui kekuatan struktur oleh Negara Usmani sehingga menjelman menjadi sistem pendidikan Usmani abad ke-16.

Di Negara Usmani pembangunan sosial tidak hanya meliputi aspek manusia saja, tetapi juga seluruh aspek kehidupan baik itu manusia, hewan dan tumbuhan.

\footnotetext{
${ }^{25}$ Halil Inalcik.The Ottoman Empire The Classical Age 1300-1600, hlm 298-299.

${ }^{26}$ Guy Burak.The Second Formation of Islamic Law: The Hanafi School in the Early Modern Ottoman Empire (NewYork: Cambridge University Press, 2015), hlm 96.
} 
Manusia tentu saja menikmati pembangunan sosial yang menyeluruh, tetapi ternyata hewan juga menjadi bagian pembangunan sosial yang berprikemanusiaan. Kecintaan manusia terhadap hewan sudah menjadi bagian dari kebudayaan Islam. Di Negara Usmani abad ke-16, hewan merupakan makhluk hidup yang tidak dapat dipisahkan dari kehidupan manusia. Sebagai wujud rasa syukur dan cinta pada Tuhan, orang-orang di Negara Usmani seringkali memberikan makanan baik itu kepada anjing, kucing maupun burung. Di Negara Usmani hewan akan menemukan tempat yang spesial karena mereka tidak hanya dirawat tetapi juga dicintai. Beberapa pejabat Usmani terlibat dalam pembuatan fasilitas sosial untuk memenuhi kebutuhan hewan. Pada Di Istanbul tahun 1544, Luthfi Paşa, mendonasikan secara khusus sebuah sumber air untuk minum para pelancong dan hewan yang dibawanya. ${ }^{27}$ Selain itu ada juga rumah burung ( $k$ ussevi) untuk menaruh makanan dan tempat berlindung bagi burung ketika hujan atau turun salju. ${ }^{28}$ Dengan demikian pembangunan sosial di Negara Usmani telah meliputi pembangunan seutuhnya terhadap makhluk hidup. Jadi aspek pemerintah dengan baik mampu membangun aspek kultural melalui kekuatan struktural yang dimilikinya.

Selain itu pembangunan sosial juga melibatkan aspek struktur yang dikulturkan (cultured structure). Dalam hal ini terdapat kebijakan pemerintah yang kemudian diadopsi oleh masyarakat sehingga menjadi kebiasaan. Tentu saja hal paling mencolok dalam Negara Usmani adalah adanya dominasi dari Islam aliran Sunni. Keberadaan Sunni di dalam Negara Usmani sangat esensial sebagai pengikat sosial (social cohesion) yang menyatukan masyarakat Usmani secara umum. Abad ke-16 diwarnai oleh adanya ketegangan dan konflik antara Sunni dan Syiah sehingga

\footnotetext{
${ }^{27}$ Ekrem Buğra Ekinci, "The Ottoman's exemplary treatment of street animals," https://www.dailysabah.com/feature/2015/01/18/the-ottomans-exemplary-treatment-of-streetanimals

${ }^{28}$ Şebnem Akalın, "Kuşevi” dalam Diyanet Islam Ansiklopedisi jilid 26 (2002), hlm 472-473. http://www.islamansiklopedisi.info/dia/pdf/c26/c260297.pdf
} 
pemerintah melakukan intervensi melalui kekuatan struktur untuk memaksakan dominasi Sunni atas Syiah. Tentu saja ini bukan bentuk kekerasan beragama karena ketika itu Syiah yang dipimpin oleh pendiri Negara Safavid, Sah Ismail, terus memberikan ancaman kepada Negara Usmani. ${ }^{29}$ Pasukan Syiah yang disebut Kızılbaş (topi merah) menjadi pendukung utama Sah Ismail. Mereka selalu melancarkan pemberontakan kepada Usmani. Pada tahun 1502 terdapat desasdesus bahwa di kota Istanbul terdapat 500 anggota Kızllbaş. Sedangkan pemberontakan Kızılbaş yang cukup mengancam Negara Usmani adalah pemberontakan yang dipimpin oleh Sahkulu di wilayah Tekke tahun $1511 .^{30}$ Untuk menumpas Kızılbaş maka Sultan Selim I (1512-1520) mengadakan ekspedisi melawan Sah Ismail di Perang Çaldıran tahun 1514. Sebelum menumpas Sah Ismail dan Kızılbaş, Selim I mengumpulkan para ulama untuk memberikan fatwa haram kepada Kızılbaş. Seorang ulama bernama Sarıgörez Nureddin Hamza menyatakan bahwa, "mereka (Sah Ismail dan pengikutnya) telah menghina syariat dan tradisi Nabi Muhammad SAW. Mereka juga telah menghina agama Islam, pengetahuan agama dan Quran." ${ }^{31}$ Struktur tentu saja tidak mengizinkan dan sudah melarang persebaran ajaran Syiah yang dibawa oleh Sah Ismail dan Kızılbaş. Namun seiring dengannya waktu maka masyarakat Usmani secara perlahan menjadikan Sunni sebagai ajaran yang membudaya dan dominan dalam masyarakat Usmani dan Syiah sebagai ajaran marjinal yang tidak populer. Tentu saja dominasi Sunni dalam masyarakat Usmani yang telah membudaya merupakan unsur kuat yang membentuk kohesi sosial (social cohesion).

\footnotetext{
${ }^{29}$ Kaya Şahin.Empire and Power in the Reign of Süleyman: Narrating the Sixteenth-Century Ottoman World (New York: Cambridge University Press, 2013), hlm 25.

${ }^{30}$ H. Erdem Çıpa.The Making of Selim, hlm 43-44; İyas Üzüm,’Kızılbaş,” dalam Diyanet İ́slam Ansiklopedisi jilid 25 (2002), hlm 547. http://www.islamansiklopedisi.info/dia/pdf/c25/c250347.pdf ${ }^{31}$ Abdurrahman Atçıl, "The Safavid Threat and Juristic Authority in the Ottoman Empire during the 16th Century,” in International Journal Middle Eastern Studies, 49 (2017), hlm 299.
} 


\section{Proses Sosial}

Proses sosial merupakan unsur yang sangat penting dalam pembangunan sosial. Dalam unsur ini kita akan melihat bagaimana masyarakat berperan penting dalam menentukan jalannya pembangunan. Menurut sosiolog Paulus Wirutomo, proses sosial adalah "segala dinamika interaksi sehari-hari antar anggota masyarakat yang belum terstruktur (structured) maupun mengkultur (cultured). Melalui proses sosial yang dinamis dan kreatif, individu maupun kelompok dapat

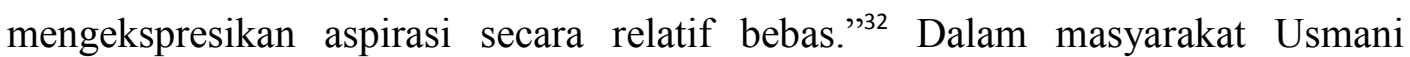
terdapat beberapa kegiatan yang menjadi pusat negosiasi masyarakat yang mampu mempengaruhi perubahan struktur dan kultur. Ternyata proses sosial tidak hanya terjadi di masa modern dan posmodern, tetapi juga terjadi dalam periode modern awal.

Pada pertengahan abad ke-16, kedai kopi (kahvehane) menjadi tempat bernegosiasi dan berkumpul masyarakat dari berbagai kalangan. Menurut sejarawan İbrahim Peçevi, hingga tahun 1554/55 atau 962 Hijriah, tidak ada kedai kopi di Negara Usmani. Konon kedai kopi pertama di Istanbul dibuka oleh orang Aleppo bernama Hakam dan orang Damaskus yang bernama Shams. Mereka membuka kedai kopi di distrik Tahtakale, Istanbul. ${ }^{33}$ Sedangkan sejarawan Katip Çelebi menyatakan bahwa kedai kopi pertama di Istanbul dibuka pada 1543. Sementara sejarawan Mustafa Ali menyebut bahwa kedai kopi pertama dibuka antara 1552 atau $1553 .^{34}$

\footnotetext{
${ }^{32}$ Paulus Wirutomo, "Mencari Makna Pembangunan Sosial," hlm 107.

${ }^{33}$ Cemal Kafadar, "A History of Coffee," hlm 51. https://sites.duke.edu/rethinkingglobalcities/files/2014/09/64Kafadar16-coffeehistory.pdf ${ }^{34}$ Alan Mikhail, "Gender, Urban Spaces and the Ottoman Coffee House," dalam Dana Sajdi (ed).Ottoman Tulips, Ottoman Coffee: Leisure and Lifestyle in the Eighteenth Century (New York: IB Tauris, 2007), hlm 138.
} 
Sejak saat itu kedai kopi mulai ramai dikunjungi oleh banyak orang. Menurut sejarawan Cemal Kafadar Awalnya keberadaan kedai kopi ditentang oleh para ulama di Istanbul karena melihat kopi sebagai minuman yang berbahaya karena membuat orang-orang terus melakukan aktivitas di sana tanpa ingat harus pergi ke masjid. ${ }^{35}$ Dibukanya kedai kopi di Istanbul dan Kairo telah mendorong terbentuknya ruang bagi masyarakat melakukan negosiasi dan interaksi terhadap keberadaan pembangunan struktural dan kultural. Meskipun demikian sejarawan Alan Mikhail mengingatkan agar kita tidak terpaku pada konsep ruang privat dan ruang publik yang digagas oleh sosiolog Jurgen Habermas dalam melihat kedai kopi. Kedai kopi di Negara Usmani tidak mengenal dikotomi privat dan publik, terkadang batasan keduanya kabur di Negara Usmani. Kedai kopi bisa menjadi tempat domestik, tempat bisnis dan mengisi waktu luang, perpanjangan dari jalanan dan pasar, pusat hiburan, ruang untuk berkomunikasi, tempat membaca hingga dunia kerumitan (a realm of distraction). ${ }^{36}$ Dengan demikian sebenarnya kedai kopi menjadi tempat yang sangat cocok untuk melakukan negosiasi struktur dan kultur yang ada dalam Negara Usmani. Puncak negosiasi struktur dan kultur di kedai kopi sebenarnya terjadi pada abad ke-18 ketika tentara Janisari mulai menguasai bisnis kedai kopi, Mereka menjadikan kedai kopi sebagai saran mendiskusikan masalah politik, bahkan membentuk oposisi terhadap pemerintahan. ${ }^{37}$ Namun abad ke-16 tetap menjadi titik tolak yang tepat untuk melihat kemunculan proses sosial yang mampu mendorong masyarakat berpartisipasi dalam menegosiasikan struktur dan kebudayaan. Hal ini juga membuktikan bahwa kedai kopi dapat menjadi kontrol atas pembangunan sosial yang dilakukan melalui pembangunan struktural dan kultural.

\footnotetext{
${ }^{35}$ Cemal Kafadar, "A History of Coffee," hlm 51.

${ }^{36}$ Alan Mikhail, "Gender, Urban Spaces and the Ottoman Coffee House," hlm 135-136.

${ }^{37}$ Ali Çaksu, "Janissary Coffee House in Late Eighteenth Century Istanbul," dalam Dana Sajdi (ed).Ottoman Tulips, Ottoman Coffee: Leisure and Lifestyle in the Eighteenth Century (New York: IB Tauris, 2007), hlm 119.
} 


\section{Kesimpulan}

Masalah mengenai "abad keemasan" memang sangat menarik untuk diteliti lebih lanjut. Kebangkitan dan keruntuhan sebuah negara adalah permasalahan yang terus melanda sejarah negara dan imperium. Bahkan hingga abad ke-18, sejarawan Edward Gibbons saja masih menggunakan pendekatan "kebangkitan dan keruntuhan" untuk menjelaskan sejarah Imperium Romawi. Makalah ini telah membahas bagaimana "abad keemasan" berjalan di dalam Negara Usmani. Negara Usmani adalah negara besar yang mencapai puncak keemasan pada abad ke-16, khususnya ketika berada di bawah pemerintahan Sultan Suleyman Kanuni (15201566).

Melalui topik pembangunan sosial dengan pendekatan struktur, kultur dan proses, maka kita dapat mengetahui bahwa pada masa "abad keemasan" Negara Usmani benar-benar menjalankan pembangunan sosial yang menyeluruh dan tidak sektoral. Pembangunan tidak hanya terfokus pada peningkatan ekonomi secara kuantitatif, tetapi juga memperhatikan kualitas hidup masyarakat. Dalam hal ini Negara Usmani melakukan pembangunan sosial humaniora pada abad ke-16. Pembangunan sosial yang menyeluruh harus dilihat dalam kerangka struktur, kultur dan proses sosial sebagai elemen dasar kehidupan bermasyarakat.

Kekuatan struktur Negara Usmani mampu memberikan paksaan kepada masyarakat dengan berbagai perangkat seperti hukum kanun dan syariat. Kanun dan syariat merupakan produk dari pembangunan struktural di Negara Usmani. Meskipun demikian kita jangan melupakan bahwa hukum kanun dan syariat merupakan bagian dari proses kultur yang distrukturkan (structured culture) karena Negara Usmani juga memiliki konsep khalifah dan adalet yang menekankan pentingnya keadilan dalam mengatur dan mengontrol masyarakat. Untuk itu 
Negara Usmani mengkulturkan adalet dan khalifah ke dalam wujud hukum kanun dan syariat.

Pembangunan kultural juga bagian dari elemen pembangunan sosial. Kebudayaan yang telah mendarah daging atau hasil dari cipta, rasa dan karsa manusia kemudian distrukturkan sehingga mendorong adanya pembangunan sosial humaniora. Beberapa kebijakan pembangunan struktural yang mendasarkannya pada aspek kultural adalah pengadopsian konsep cabang ilmu yang digagas oleh Taşköprizade Ahmed Efendi pada abad ke-16. Selain itu kebiasaan menyayangi hewan seperti burung, kucing dan anjing mendorong kekuatan struktur Negara Usmani untuk menjadikan kultur tersebut sebagai kebijakan. Untuk itu muncul adanya lembaga wakaf yang peduli terhadap hewan. Dalam pembangunan kultural terdapat juga adanya struktur yang dikulturkan (cultured structure) seperti homogenisasi aliran Sunni yang sudah terjadi akibat kebijakan Negara Usmani yang berkonflik dengan Sah Ismail dari Negara Safavid (penganut Syiah).

Pembangunan sosial juga harus melibatkan aspek proses sosial. Dalam proses sosial terdapat negosiasi dan interaksi antarmasyarakat sehingga struktur dan kultur dapat diperdebatkan dan dibicarakan. Dalam Negara Usmani terdapat kedai kopi (kahvehane) yang berperan penting sebagai ruang bersama untuk melakukan interaksi. Di kedai kopi,struktur dan kultur kembali dibicarakan dan dinegosiasikan. Bahkan terkadang kedai kopi dapat menjadi tempat perdebatan peristiwa-peristiwa politik dan tempat melakukan oposisi terhadap sultan. Singkatnya, penulis berargumen bahwa pada abad ke-16, Negara Usmani memang mengalami "abad keemasan." Hal tersebut ditandai dengan adanya pembangunan sosial yang bertumpu pada sosial humaniora daripada terpusat pada sektor ekonomi saja. Pembangunan sosial ini telah melibatkan elemen dasar struktur, kultur dan proses sebagai elemen dasar manusia. 


\section{Daftar Pustaka}

Akalın, Şebnem, "Kuşevi” dalam Diyanet Islam Ansiklopedisi jilid 26 (2002), hlm 472-473. http://www.islamansiklopedisi.info/dia/pdf/c26/c260297.pdf

Atç1l, Abdurrahman, "The Safavid Threat and Juristic Authority in the Ottoman Empire during the 16th Century," in International Journal Middle Eastern Studies, 49 (2017), hlm 299.

Barkey, Karen.Empire of Difference: The Ottomans in Comparative Perspective (New York: Cambridge University Press, 2008)

Burak, Guy.The Second Formation of Islamic Law: The Hanafi School in the Early Modern Ottoman Empire (NewYork: Cambridge University Press, 2015)

_Çağrıc1, Mustafa, “Adalet,” dalam Diyanet Islam Ansiklopedisi jilid 1 (1988), hlm 341. http://www.islamansiklopedisi.info/dia/pdf/c01/c010419.pdf

Çaksu, Ali, "Janissary Coffee House in Late Eighteenth Century Istanbul," dalam Dana Sajdi (ed).Ottoman Tulips, Ottoman Coffee: Leisure and Lifestyle in the Eighteenth Century (New York: IB Tauris, 2007)

Çıpa, H. Erdem.The Making of Selim: Succession, Legitimacy and Memory in the Early Modern Ottoman World (Indiana: Indiana University Press, 2017)

Darling, Linda T. Revenue-Raising and Legitimacy: Tax Collection and Finance Administration in the Ottoman Empire 1560-1660 (Leiden, New York, Koln: Ej. Brill, 1996)

Ekinci, Ekrem Buğra, "The Ottoman's exemplary treatment of street animals," https://www.dailysabah.com/feature/2015/01/18/the-ottomans-exemplarytreatment-of-street-animals 
El-Haj, Rifa'at Abou.Formation of the Modern State: the Ottoman Empire Sixteenth to Eighteenth Century (New York: Syracuse University Press, 2005)

Evliya Çelebi. Günümüz Türkçesiyle Evliya Çelebi Seyahatnamesi: İstanbul (edit oleh Seyit Ali Kahraman-Yücel Dağşı) (İstanbul: Yapı Kredi Yayınları 2006)

Farid Alatas, Syed.Applying Ibn Khaldun: The Recovery of a Lost Tradition in Sociology (New York: Routledge, 2014)

Fleischer, Cornell.Tarihçi Mustafa Ali: Bir Osmanlı Aydın ve Bürokratı (İstanbul: Türkiye Ekonomik ve Toplumsal Tarih Vakfı, 1996).

Gellner, Ernest.Muslim Society (New York: Cambridge University Press, 1981)

Hanioğlu, M. Şükrü.A Brief History of Late Ottoman Empire (New Jersey: Princeton University Press, 2008)

Inalcik, Halil.The Ottoman Empire The Classical Age 1300-1600 (New Haven: Phoenix, 2001)

Kafadar, Cemal "The Myth of Golden Age: Ottoman Historical Consciousness in the Post-Suleymanic Era," dalam Halil Inalcik dan Cemal Kafadar (ed).Suleyman The Second and His Time (Istanbul: ISIS, 1993)

Kafadar, Cemal, “A History of Coffee," hlm 51 https://sites.duke.edu/rethinkingglobalcities/files/2014/09/64Kafadar16coffeehistory.pdf

Kolodziejczyk, Dariusz, "Khan, Caliph, Tsar and Imperator: The Multiple Identites of Ottoman Sultan," dalam Peter Fibiger Bang \& Dariusz Kolodziejczyk (ed).Universal Empire: A Comparative Approach to Imperial Culture and 
Representation in Eurasian History (New York: Cambridge University Press, 2012)

Mikhail, Alan, "Gender, Urban Spaces and the Ottoman Coffee House," dalam Dana Sajdi (ed).Ottoman Tulips, Ottoman Coffee: Leisure and Lifestyle in the Eighteenth Century (New York: IB Tauris, 2007)

Peçevi İbrahim Efendi.Peçevi Tarihi 1 (penerjemah: Bekir S1tkı Baykal) (Ankara: Başbakanlı Matbaası, 1981)

Şahin, Kaya.Empire and Power in the Reign of Süleyman: Narrating the SixteenthCentury Ottoman World (New York: Cambridge University Press, 2013)

Sai Mustafa Çelebi.Tezkiretü'l Bünyan ve Tezkiretü'l-Enbiye: Mimar Sinan'ın Anıları (edit oleh Doğan Kuban) (İstanbul: Koç Kültür Sanat Tanıtım A.Ş, 2003)

Stimely, Keith, "Oswald Spengler: An Introduction to His Lifes and Ideas," https://www.ihr.org/jhr/v17/v17n2p-2_Stimely.html

Üzüm, İyas, ”Kızılbaş," dalam Diyanet İslam Ansiklopedisi jilid 25 (2002), hlm 547. http://www.islamansiklopedisi.info/dia/pdf/c25/c250347.pdf

Wirutomo, Paulus, "Mencari Makna Pembangunan Sosial: Studi Kasus Sektor Informal di Kota Solo," dalam Masyarakat: Jurnal Sosiologi, Vol 18, No.1, (2013), hlm 106. file:///C:/Users/personal/Downloads/3735-7073-2-PB.pdf

Yavuz, Yusuf Şevki, "Taşköprizade Ahmed Efendi," dalam Diyanet Islam $\begin{array}{llllll}\text { Ansiklopedisi } & \text { jilid } & 40 & \text { (2011), } & \text { hlm } & 151 .\end{array}$ http://www.islamansiklopedisi.info/dia/pdf/c40/c400077.pdf

Yerasimos, Stefanos.Süleymaniye (İstanbul: Yapı Kredi Yayınları 2002) 
Frial R. Supratman

88 | TamaddunVol. 7 , No. I, Januari - Juni 2019 